\title{
Physico-mechanical Properties of Glass Fibre Reinforced Biophenolic Elastomer Composite
}

(Sifat Fiziko-Mekanikal Gentian Kaca Biofenolik Elastomer Komposit Bertetulang)

\author{
ZuHAili ZAKARIA, SARANi ZAKARIA*, RASIDI Roslan, CHIN HuA CHIA, SHARIFAH NABIHAH SYED JAAFAR, \\ UMAR ADLI AMRAN \& SINYEE GAN
}

\begin{abstract}
In this study oil palm empty fruit bunches (EFB) fibres was used to synthesize biophenolic resin (BPR) at a different formaldehyde/liquefied empty fruit bunches (F/LEFB) molar ratio which is 1.0, 1.5 and 2.0. The higher molar ratio of $F /$ $\angle E F B$ used has resulted in an increased of viscosity and solid content of BPR resin. The first decomposition of BPR resin occured around 86 to $130^{\circ} \mathrm{C}$ due to the evaporation of low molecular weight substance which were water, free phenol and formaldehyde. Glass fibre reinforced biophenolic composite (BPC) and glass fibre reinforced biophenolic elastomer composite (BPEC) was successfully fabricated using BPR resin. The impact strength and flexural strain of BPEC were higher than that of BPC. The impact strength of BPEC 1.5 was the highest at $47.71 \mathrm{kJm}^{-2}$. However, the flexural strength of BPEC was lower compared with BPC, which the highest flexural strength was obtained by BPC 1.0 at 65.18 MPa. The cross-sectional image from scanning electron microscope (SEM) of BPEC and BPC confirmed the presence of epoxidized natural rubber (ENR) improved the compatibility between glass fibre and BPR resin.
\end{abstract}

Keywords: Epoxidized natural rubber; interlocking; liquefaction; oil palm empty fruit bunches; prepreg

\section{ABSTRAK}

Kajian ini dijalankan dengan menggunakan serabut tandan kosong kelapa sawit (EFB) bagi menghasilkan resin biofenolik (BPR) berdasarkan nisbah molar formaldehid/serabut tandan kosong kelapa sawit tercecair (F/LEFB) yang berbeza iaitu 1.0, 1.5 and 2.0. Nisbah molar F/LEFB yang tinggi telah menyebabkan kelikatan dan kandungan pepejal resin BPR meningkat. Penguraian pertama bagi resin BPR berlaku pada suhu sekitar 80 sehingga $130^{\circ} \mathrm{C}$ disebabkan pemeluapan bahan berat molekul yang rendah seperti air, formaldehid dan fenol. Komposit berpenguat gentian kaca $(B P C)$ dan komposit biofenolik elastomer berpenguat gentian kaca (BPEC) telah berjaya dihasilkan mengguna resin BPR. Kekuatan hentaman dan terikan lenturan BPEC adalah lebih tinggi berbanding BPC. Namun, kekuatan lenturan BPEC adalah lebih rendah berbanding BPC. Imej daripada mikroskopi imbasan elektron (SEM) bagi keratan rentas BPEC dan BPC menunjukkan kehadiran getah asli terepoksida (ENR) meningkatkan keserasian di antara resin BPR dan gentian kaca.

Kata kunci: Getah asli terepoksida; pencecairan; prapreg; saling kunci; serabut tandan kosong kelapa sawit

\section{INTRODUCTION}

Phenol-formaldehyde $(\mathrm{PF})$ resol resin, is the process consist of addition and condensation reactions between phenol and formaldehyde under alkaline conditions, has been widely used as an adhesive in the industry for a long time. Its excellent properties such as good bond strength, water resistance and low initial viscosity make it acts as an ideal choice to use as an adhesive in plywood, oriented strand board (OSB), and laminated veneer lumber (Pizzi 2003). Apart from that, PF composite also plays an important role in aerospace (Auad et al. 2007) and military industry due to its high thermal stability and fire proof properties (Abdalla et al. 2003). However, PF resin was brittle, thus, limit its usage for high end application. Glass fiber reinforced composites was most commonly used in the manufacture of composite materials. The matrix comprised organic, polyester, thermostable, vinylester, phenolic and epoxy resins. The mechanical behaviour of a fiber reinforced composite depends on the fiber strength and modulus, matrix strength and the interface bonding between the fiber/matrix to enable stress transfer. Composite materials have a wide range of industrial applications used in manufacturing industry because of good environmental resistance, better damage tolerance for impact loading, high specific strength and stiffness.

The rising concerns regarding the fluctuation of petroleum prices, depletion of fossil fuels, climate change and over security supply have led to various studies conducted to replace phenol with renewable resources. Renewable resources that are abundant in the earth and a promising material to substitute petroleumbased chemicals are lignocellulosic biomass (Azahari et al. 2017; Gan et al. 2017). The main composition in 
lignocellulose material were cellulose, hemicellulose and lignin which has $40 \%$ in dry weight (Gani \& Naruse 2007). Lignin in the lignocellulosic biomass has a high potential for the production of biophenolic resin because of its phenolic nature which a lot of phenols derivatives can be derived (Effendi et al. 2008; Siti Noorul Aina et al. 2017).

Liquefaction of biomass is one of the example process used to produce phenols derivative. Liquefaction of biomass and wood have been extensively studied by many researchers (Ahmadzadeh et al. 2008; Alma \& Basturk 2006; Lee et al. 2002; Lin et al. 1994; Pua et al. 2013). Most of biomass liquefaction was conducted using acid as the catalyst because it can increase the conversion yield. Although using alkaline catalyst produces a lower residue, it was not effective as an acid catalyst to produce high amount of combined phenol (Alma et al. 1998). Sulfuric acid was the best catalyst to liquefy empty fruit bunches (EFB) fibres (Ahmadzadeh et al. 2009). From their studies, phenol to EFB fibres weight ratio of 3:1 was the most suitable combination to obtain high liquefaction yield while the catalyst concentration used are 3-5\% at temperature around $130-150^{\circ} \mathrm{C}$ for $60-90 \mathrm{~min}$. A study by Roslan et al. (2014), resol type phenolic resin made from liquefied EFB for plywood adhesive application was also studied and the shear strength result showed that it passed the minimum requirement of Japanese Industrial Standard JIS K-6852.

Epoxidized natural rubber (ENR) was a modified natural rubber (NR) form when peracetic acid is reacted with natural rubber, cis-1,4-isoprene (Hamzah et al. 2012). These epoxides make ENR vulnerable to all kinds of chemical reactions that involved hydrogen donor groups such as carboxylic acid, amines and alcohols (Phinyocheep et al. 2005). There are two types of ENR, which are ENR-25 and ENR-50 that are commercially available. ENR-50 consist of $50 \%$ mole epoxidation and ENR-25 is $25 \%$ epoxidation resin. The miscibility of the compounds will allow molecular interactions to occur, such as dipole-dipole interactions and donor-acceptor type of weakly acidic hydrogen. Theoretically, ENR should be compatible with proton-donating polymers such as phenolic resin (Kallitsis \& Kalfoglou 1989).

The brittleness of phenolic resin can be overcome by introducing a toughening agent. Rubber was one of the toughening agent used to reduce the brittleness. Types of rubber that are commonly used were nitrile rubber because it is compatible with phenolic resin (Kaynak \& Cagatay 2006). Introducing ENR into biophenolic composite was expected to have elastomeric properties and improved resistance towards impact. Although utilization of liquefied EFB to produce biophenolic resin has been explored previously (Ahmadzadeh et al. 2009; Roslan et al. 2014), however, incorporation of ENR as a toughening agent has been rarely reported so far. Therefore, the aim of this study was to investigate the physico-mechanical properties of glass fibre reinforced biophenolic elastomer.

\section{MATERIALS AND METHODS}

\section{MATERIALS}

Oil palm empty fruit bunches (EFB) fibres was supplied by Szetech Engineering and E-glass fibres which have a density of $2.58 \mathrm{~g} / \mathrm{cm}^{3}, 0.55-0.77 \mathrm{~mm}$ in diameter and continuous fibre were supplied by RTG Intech Sdn. Bhd. The natural rubber used was ENR-50 which was 50\% mole epoxidation bought from Malaysian Rubber Light. Industrial grade phenol (98\%) used was from Chemzone Sdn. Bhd. Methanol, toluene, analytical grade sulfuric acid (98\%), formalin (37\% formaldehyde) and sodium hydroxide $(\mathrm{NaOH})$ were purchased from Sigma-Aldrich.

\section{LIQUEFACTION OF EFB FIBRES}

Liquefaction of EFB fibres was conducted using method from Amran et al. (2015) with a light modification. The weight ratio of phenol to EFB fibres (P/EFB) was 3:1 and sulfuric acid ( $3 \%$ based on the phenol weight) was used as catalyst. The reaction was carried out in an oil bath at $150^{\circ} \mathrm{C}$ for 90 min to produce black and viscous liquid. After that, $400 \mathrm{~mL}$ of methanol was then added to dilute the viscous liquid. After the dilution, the liquid mixture was filtered with a filter paper (Whatman No. 1) to remove residues. The filtered liquid was then put in a rotary evaporator to remove the excess methanol and the liquefied EFB (LEFB) was collected for subsequent resinification process.

\section{RESINIFICATION}

The resinification was carried out by reacting LEFB with formalin (37\% formaldehyde solution) as the crosslinking agent using a molar ratio of F/LEFB 1.0 in an alkaline medium. Sodium hydroxide (40 wt. \%) aqueous solution was added in a two-step process. The first $60 \mathrm{~min}$ of the reaction, 5 wt. \% (based on LEFB weight) of $\mathrm{NaOH}$ solution was added and the temperature was set at $65^{\circ} \mathrm{C}$. Then the temperature was increased to $85^{\circ} \mathrm{C}$ and 20 wt. \% (based on LEFB weight) of $\mathrm{NaOH}$ solution was added. The reaction was continued for another $60 \mathrm{~min}$. After finished, the resinification process was repeated using different molar ratio of F/LEFB which are 1.5 and 2.0. Three biophenolic resin (BPR) were produced using two-steps process with a (F/LEFB) molar ratio of $1.0,1.5$ and 2.0.

\section{PREPARATION OF EPOXIDISED NATURAL RUBBER (ENR) SOLUTIONS}

The epoxidised natural rubber (ENR) solution was prepared by dissolving $10 \mathrm{~g}$ of ENR in $100 \mathrm{~mL}$ of toluene to produce rubber solutions with $10 \%$ solid content. The process was conducted in $1000 \mathrm{~mL}$ round bottom flask attached to a reflux condenser system equipped with an overhead stirrer. The process was carried out at $80^{\circ} \mathrm{C}$ for $6 \mathrm{~h}$ in an oil bath. 
PREPARATION OF GLASS FIBRE REINFORCED BIOPHENOLIC COMPOSITE (BPC)

The BPC composite was prepared using hand lay-up technique and followed by compression molding (Amran et al. 2015). Total glass fibre loading used was 40 wt. $\%$ of total composite weight. The other $60 \mathrm{wt} \%$ was the total resin. Each composite consists of seven layers of glass fibres which stacked together (Figure 1). The lay-ups were kept in an oven for $14 \mathrm{~h}$ at $60^{\circ} \mathrm{C}$ to reach the semi cured stage. The semi cured lay-ups were then hot pressed for $15 \mathrm{~min}$ at $105^{\circ} \mathrm{C}$ in a mold with a $150 \times 150 \times 3 \mathrm{~mm}$ dimensions. The composite produced using biophenolic resin F/LEFB molar ratios of 1.0, 1.5 and 2.0 were labelled as BPC 1.0, BPC 1.5 and BPC 2.0, respectively.

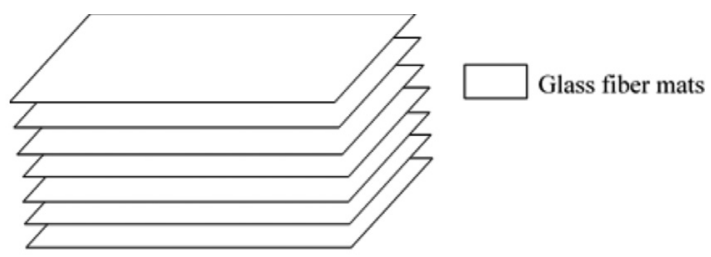

FIGURE 1. Glass fibre reinforced biophenolic composite

\section{PREPARATION OF GLASS FIBRE REINFORCED BIOPHENOLIC ELASTOMER COMPOSITE (BPEC)}

The glass fibre reinforced biophenolic elastomer composite (BPEC) was produced using similar method as $\mathrm{BPC}$ composite. However, the glass fibre prepreg on the third and fifth layer were modified as shown in Figure 2. The modified glass fibre was prepared by applying 35 wt. \% of ENR solution from the weight of the glass fibre mats onto both sides of the glass fibre mats. For example if the weight of one glass fibre mat is $100 \mathrm{~g}$, then $35 \mathrm{~g}$ of ENR solution will be applied to the mats to produce ENR prepreg. The rubber coated glass fibres were dried in an oven for $30 \mathrm{~min}$ at $60^{\circ} \mathrm{C}$ to remove the toluene. After

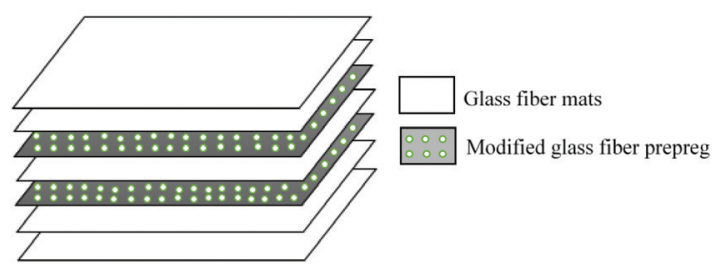

FIGURE 2. Glass fibre reinforced biophenolic elastomer composite

drying, the rubber coated glass fibres was then modified by drilling $3 \mathrm{~mm}$ diameter holes as shown in Figure 3 . The reason for drilling holes onto the prepreg was to allow BPR resin to pass-through and interlock between the mats during heated compression. The composite produced was labelled as BPEC 1.0, BPEC 1.5 and BPEC 2.0 according to the BPR resin F/LEFB molar ratio of 1.0 , 1.5 and 2.0 , respectively.

\section{CHARACTERIZATION OF BPR RESIN}

Thermogravimetric analysis (TGA) was conducted using Mettler-Toledo (TGADSC1). A total of $15 \mathrm{mg}$ of resin was placed in $30 \mathrm{~mL}$ aluminum crucible which was then subjected to heating in nitrogen atmosphere with a heating rate of $10^{\circ} \mathrm{C} / \mathrm{min}$ starting from 25 to $900^{\circ} \mathrm{C}$. The rate of decomposition and weight changes of the BPR resins were studied. The $\mathrm{pH}$ and viscosity of the BPR and commercial resins were tested using a Sartorius $\mathrm{PB}-10 \mathrm{pH}$ meter and DV-I prime Brookfield viscometer, respectively. The solids content of resins were calculated using AND moisture analyzer MX-50 model.

\section{MECHANICAL TEST OF BPC AND BPEC COMPOSITE}

Charpy impact test and flexural test were carried out according to ASTM D6110 and ASTM D790, respectively. The impact test was performed on Instron CEAST 9050

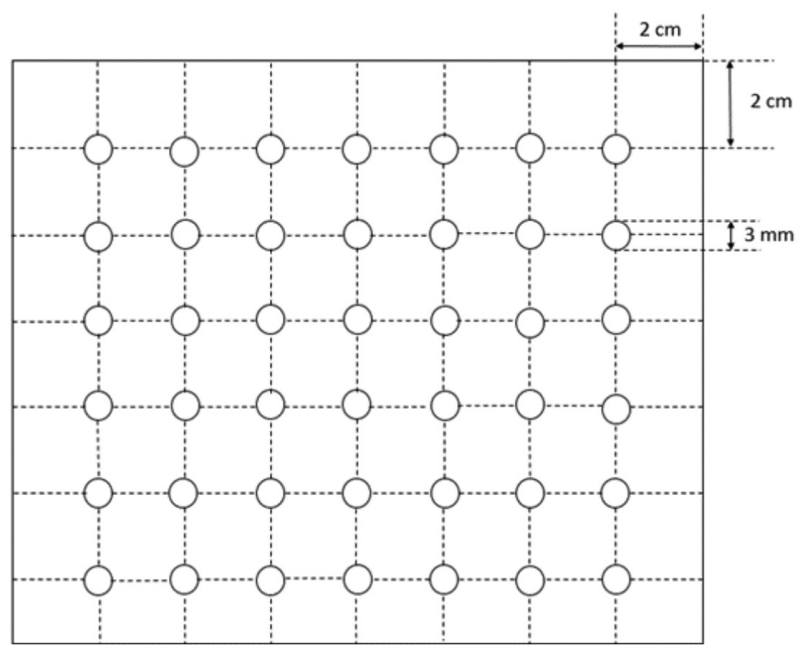

FIGURE 3. Modified glass fibre prepreg 
machine. For the flexural test, three-point bending with a nominal specimen dimension of $90 \times 13 \times 3 \mathrm{~mm}$ was carried out using a Universal Testing Machine (Testometric M500-50CT). The span was $50 \mathrm{~mm}$ and the crosshead speed was $10 \mathrm{~mm} / \mathrm{min}$. The value obtained represents the average of five specimens tested.

\section{MORPHOLOGICAL ANALYSIS OF BPC AND BPEC COMPOSITE}

The morphological structure of BPC and BPEC were investigated using scanning electron microscope (SEM) model Philip XL 30 to observe the fractography of the surfaced of BPEC, and BPC composites, the interaction between glass fibres, ENR-50 and biophenolic resin. The impacted sample was cut cross-sectional from the impacted sample using a cutter and coated with a thin layer of gold.

\section{RESULTS AND DISCUSSION}

\section{CHARACTERIZATION OF BPR RESIN}

The physical properties of biophenolic resin were shown in Table 1 . The results showed that the amount of formaldehyde used in the reaction greatly influenced the viscosity of the biophenolic resin. It was known that resin viscosity was influenced by F/LEFB ratio, temperature and non-volatile chemicals (Haupt \& Sellers 1994). Higher formaldehyde content resulted in the increase of viscosity of the BPR resin produced because higher formaldehyde content tends to speed up the polymerization process. The solid content in the BPR resin increased as the molar ratio of F/LEFB increased. This is because solid content of thermoset resins is correlated with the degree of polymerization between reactive monomer in the resin (Lenghaus et al. 2001). Higher molar ratio of F/LEFB will produce more complex and larger polymer structures. The potential for the formaldehyde to react with the phenolic ring will increase when the concentrations of formaldehyde is higher. Branching will be formed quickly and a lot of complex structures and solid will be produced (Lenghaus et al. 2001).

\section{TGA ANALYSIS OF BPR RESIN}

Figure 4 shows the weight loss of BPR resin produced at different F/LEFB molar ratios. The first decomposition was around 86 to $130^{\circ} \mathrm{C}$ due to the evaporation of low molecular weight substance which was water, free phenol

TABLE 1. Physical properties of biophenolic resin

\begin{tabular}{lccc}
\hline & $\mathrm{pH}$ & $\begin{array}{c}\text { Solid content (wt. } \\
\%)\end{array}$ & $\begin{array}{c}\text { Viscosity } \\
(\mathrm{cP})\end{array}$ \\
\hline BPR 1.0 & 9.18 & 62.96 & 64.4 \\
BPR 1.5 & 9.40 & 68.14 & 96.4 \\
BPR 2.0 & 9.99 & 68.26 & 200 \\
\hline
\end{tabular}

and formaldehyde ( $\mathrm{Hu}$ et al. 2012). At 130 to $380^{\circ} \mathrm{C}$, second decomposition occurred where carbon dioxide, carbon monoxide and methylene were released due to the elimination of carbonyl, diphenyl ether and hydroxymethyl groups as the result of the cleavage of methylene bridges. Increased in F/LEFB ratio would increase the amount of methylene bridges which produced when phenolic hydroxyl crosslinked with formaldehyde. This was proved by the increase in weight loss in second $\left(130-380^{\circ} \mathrm{C}\right)$ and third $\left(380-500^{\circ} \mathrm{C}\right)$ degradation when $\mathrm{F} / \mathrm{LEFB}$ ratio of the BPR resin increased (Figure 4). The third decomposition occurred at 380 to $500^{\circ} \mathrm{C}$ is due to the thermal pyrolysis of methylene bridge in the ortho-para and para-para position (Roslan et al. 2014). It also showed that BPR resin with higher F/LEFB ratio possessed higher crosslinking density which could affect the mechanical properties of the composite. After the curing process, most of the structure in the phenolic resin consists of phenolic methylene bridge. These 3D phenolic networks will start to degrade when the temperature was increased (Chen et al. 2012). Degradation of the $3 \mathrm{D}$ network started in $700^{\circ} \mathrm{C}$ where no changes were observed on the weight resin because it has turned into ashes.

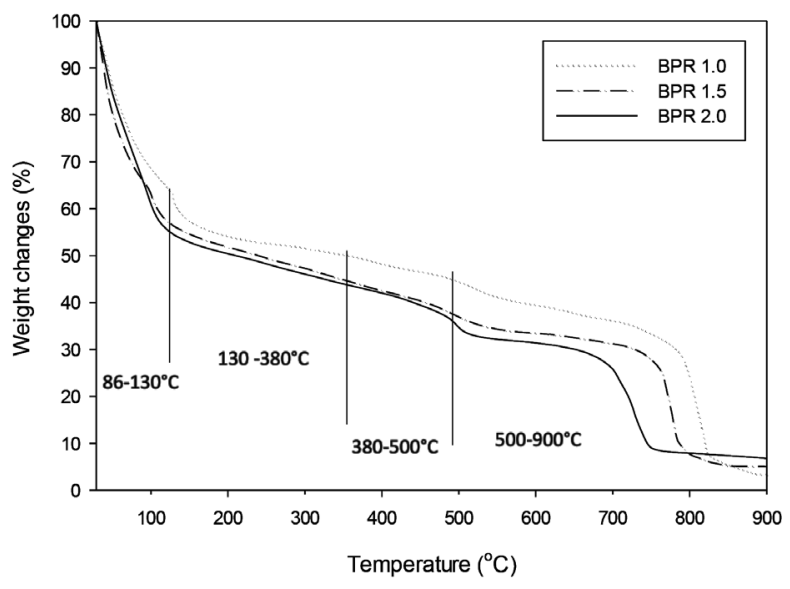

FIGURE 4. TGA weight loss (\%) of BPR 1.0, 1.5 and 2.0

\section{CHARPY IMPACT TEST AND FLEXURAL TEST}

Figure 5 shows scheme of probable crosslinking mechanism between ENR-50 and BPR resin and Figure 6 portrays the impact strength of BPC and BPEC. The results showed that the impact strength of BPEC was higher compared to BPC due to the presence of ENR which provided the compatibility between BPR resin and glass fibres. BPEC 1.5 has the highest impact strength $\left(47.71 \mathrm{kJm}^{-2}\right)$ because of the presence of ENR-50 which allowed more impact force that can be absorbed through stress distribution by the rubber particles (Amran et al. 2015). Phenolic resins and glass fibres also have low compatibility with other resins such as epoxy and polyester (Ohsawa et al. 1978). However, the addition of ENR-50 makes the two components act as matrices in composites. 
The difference in compatibility between composites without prepreg ENR-50 (BPC) and composites that have prepreg ENR-50 (BPEC) can be seen in Figures 6, 7 and 8 . The difference in impact strength between BPC and BPEC composites was also seen depends on the viscosity of BPR resin before applying it to the glass fibre. Referring to Figure 6, BPC and BPEC composites showed the highest impact strength by using BPR resin 1.5 , while the impact strength decreased for the composites produced using BPR 2.0 resins (BPC 2.0 and BPEC 2.0). BPR 2.0 resin has the highest viscosity resin (Table 1 ) when compared to other BPR resins.

A viscous resins are difficult to spread between the fibreglass and this will cause the surface of the fibreglass not fully covered. BPR resins also contain aromatic rings and two ortho- and para- positions to react with each phenol molecule. A large number of $\mathrm{OH}$ groups in BPR resin are able to crosslink with oxirane rings found in ENR-50 molecules (Amran et al. 2015). Figure 5 shows the probable crosslinking mechanism between ENR-50 and BPR resin. Both composites showed highest impact strength when BPR 1.5 resin were used. When BPR 2.0 resin were used the impact strength of BPC and BPEC dropped. This is because higher formaldehyde content tends to speed up the polymerization process. When the composite were hot pressed, crosslinking does not occurs perfectly due to some of the BPR 2.0 resin already crosslink between itself.

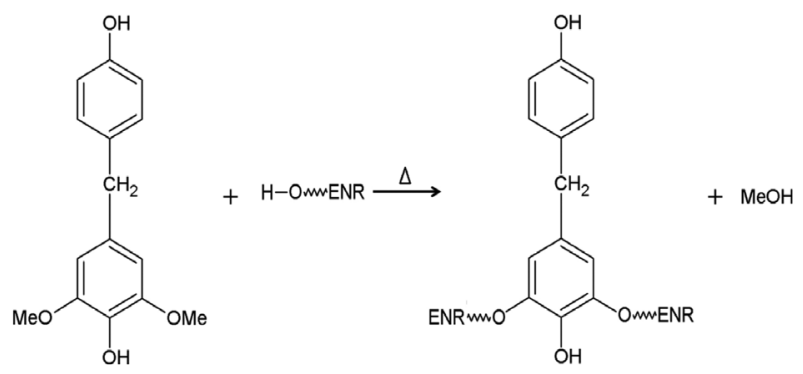

FIGURE 5. Scheme of probable crosslinking mechanism between ENR-50 and BPR resin (Amran et al. 2015)

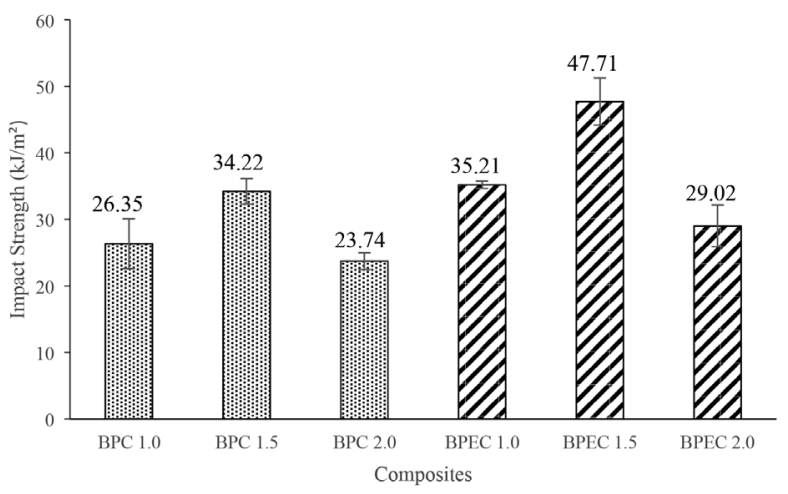

FIGURE 6. Impact strength of BPC and BPEC composites
The flexural strength and strain of the composite were shown in Figures 7 and 8. The flexural strength of BPEC composites were lower when compared with BPC composites. The ENR-50 in BPEC 1.0, 1.5 and 2.0 has altered the rigidity and gives elastomeric properties. This caused the flexural strength of the composite to reduce. The elasticity of the ENR-50 prepreg also makes it easier to change shape and dimension therefore makes it easier to be flexured. The flexural strain was higher for BPEC composite compared to BPC composite. The flexural strain of BPEC 1.0 and 2.0 composites was almost the same which is $6.255 \%$ and $6.268 \%$ except for BPEC 1.5 (4.29). The strain shown by the composites was related to the BPR resin- ENR-50 prepreg interface and glass fibres. The resin and the presence of prepreg ENR-50 increased the interface interaction between BPR resin-prepreg ENR50 and glass fibre-BPR. Thus, the BPEC composite has a high yielding strain due to its elastic properties of ENR50 and a good interface to resins and glass fibres. The flexural strength of BPC composite when using BPR 1.0 resin was $65.18 \mathrm{MPa}$ and it dropped when BPR 2.0 resin was used. For BPEC composite, BPR 1.5 resin used showed the highest flexural strength which is $35.45 \mathrm{MPa}$. Large number of OH groups in BPR 1.5 resin are able to crosslink with oxirane rings found in ENR-50 molecules which makes it harder to flexured. Among BPC composites, the flexural strain of BPR 1.5 resin was the highest which was $3.88 \%$. For BPEC composite BPR 1.5 resin showed the lowest flexural strain $(4.29 \%)$.

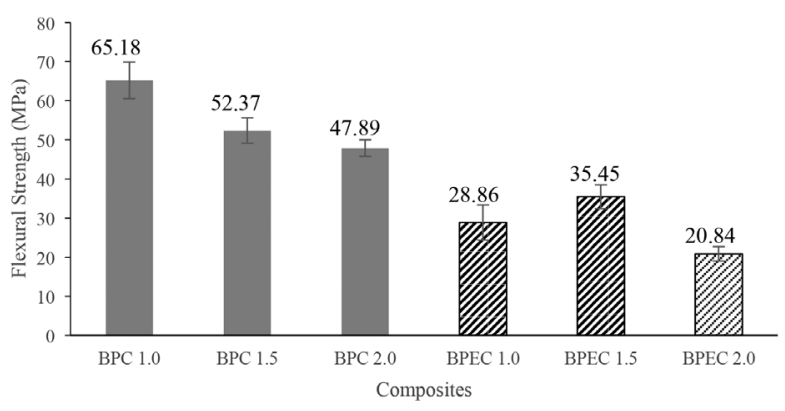

FIGURE 7. Flexural strength of BPC and BPEC composites

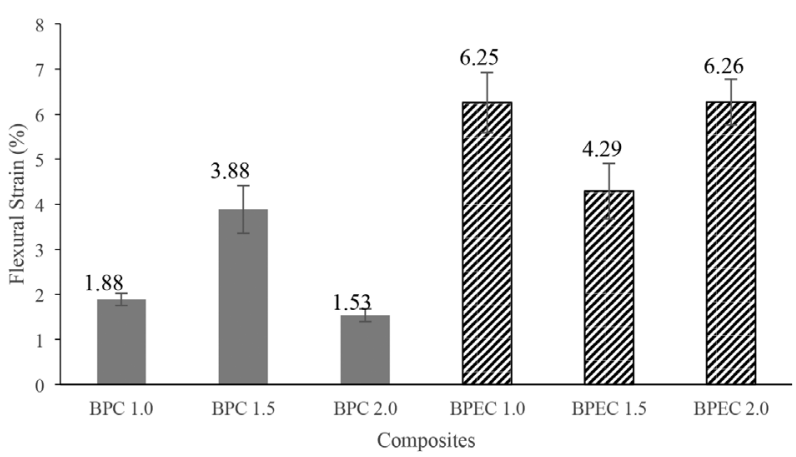

FIGURE 8. Flexural strain of BPC and BPEC composites 
CROSS-SECTIONAL SEM IMAGE OF BPC AND BPEC

Figure 9 shows the cross-sectional SEM images of BPC 1.0, BPC 1.5, BPC 2.0 (a,c,e) and BPEC 1.0, BPEC 1.5, BPEC 2.0 $(b, d, f)$. From the figure, each BPR 1.0, 1.5 and 2.0 resin which was used to produce BPC show less compatibility with glass fibres as compared to BPEC samples. Poor compatibility between biophenolic resin and glass fibres caused weak interface interaction. This has led to easy pullout effect of resin fibres and caused brittleness towards the composite. The impact strength of a composite depends on the effects of the drop-out (pull-out) and fibre fracture of a composite (Sreekala et al. 2002).

The increased in F/LEFB ratio used in the formulation of BPR resins might increase the crosslinking density of the resin. Higher crosslinking density caused the resin to be more brittle. Hence, resin with higher F/LEFB ratio would fracture more than the other resins. It can be seen that the fractured matrix of the composites was less compact due to impact fracture when the F/LEFB ratio was increased (Figure 9(a), 9(c) and 9(e)).

Previous study showed that formaldehyde could crosslink with epoxide groups (Alyamac et al.2012). Thus, by increasing the F/LEFB ratio, the crosslinking between the BPR resin and ENR might also increase. Figure 9(b), 9(d) and 9(f) shows that resin with higher F/LEFB ratio possessed better compatibility with ENR. The BPEC 2.0 sample (Figure 9(c)), show that many ENR particulates attached to its matrix forming a compact structure.

\section{CONCLUSION}

BPR resin was successfully produced in three different molar ratios of F/LEFB which were 1.0, 1.5 and 2.0. The increased of F/LEFB molar ratio has resulted in an
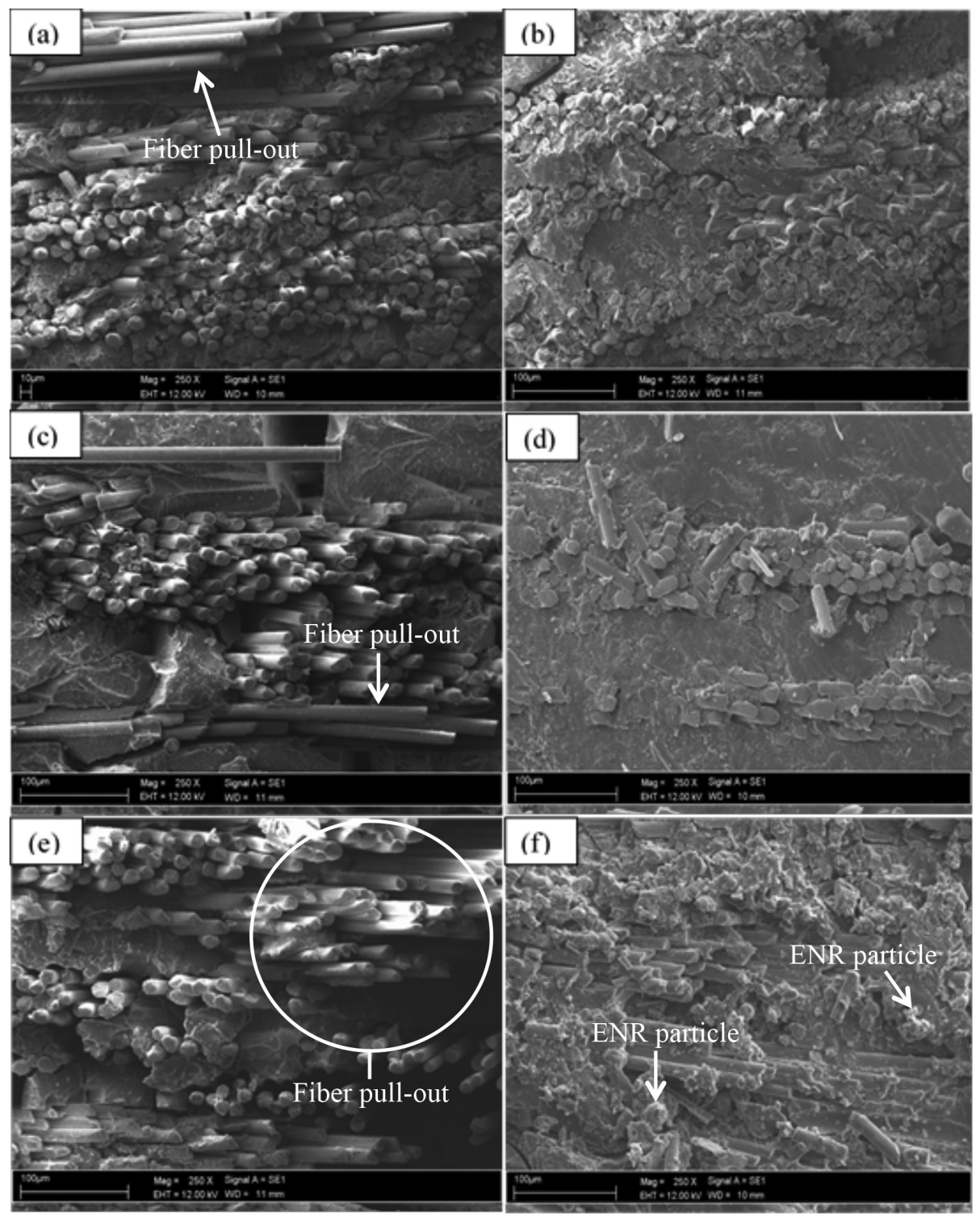

FIGURE 9. Cross-sectional SEM image of BPC 1.0, BPC 1.5, BPC 2.0 (a,c,e) and BPEC 1.0 BPEC 1.5 , BPEC $2.0(\mathrm{~b}, \mathrm{~d}, \mathrm{f})$ 
increased of viscosity and solid content. Glass fibre BPC and BPEC composites were also fabricated using BPR resin. The impact strength of BPEC composites was higher compared to BPC composites. BPC and BPEC composites showed the highest impact strength by using BPR resin 1.5, while the impact strength decreased for the composites produced using BPR 2.0 resins. The flexural strain for BPEC composites was higher than BPC composites. However, the flexural strength of BPEC composites was lower compared to BPC composites. The presence of ENR has improved the compatibility between BPR resin and glass fibre.

\section{ACKNOWLEDGEMENTS}

The authors would like to thank the financial support from research grants PRGS/1/2015/SG06/UKM/01/1, RDU160329 and Centre for Research and Instrumentation Management (CRIM) at UKM for testing services provided.

\section{REFERENCES}

Abdalla, M.O.,Ludwick,A. \& Mitchell, T. 2003. Boron-modified phenolic resins for high performance applications. Polymer 44(24): 7353-7359.

Ahmadzadeh, A., Zakaria, S. \& Rashid, R. 2009. Liquefaction of oil palm empty fruit bunch (efb) into phenol and characterization of phenolated efb resin. Industrial Crops and Products 30(1): 54-58.

Ahmadzadeh, A., Zakaria, S., Rashid, R. \& Jaafar, S.N.S. 2008. Effect of filler and thermal aging on the mechanical properties of phenolated oil palm empty fruit bunch-base composite. Sains Malaysiana 37(4): 383-387.

Alma, M.H. \& Basturk, M.A. 2006. Liquefaction of grapevine cane (Vitis vinisera L.) waste and its application to phenolformaldehyde type adhesive. Industrial Crops and Products 24(2): 171-176.

Alma, M.H., Maldas, D. \& Shiraishi, N. 1998. Liquefaction of several biomass wastes into phenol in the presence of various alkalis and metallic salts as catalyst. J. Polym. Eng. 18(3): 161-177.

Alyamac, E., Gu, H., Soucek, M.D., Qiu, S. \& Buchheit, R.G. 2012. Alkoxysilane oligomer modified epoxide primers. Progress in Organic Coatings 74(1): 67-81.

Amran, U.A., Zakaria, S., Chia, C.H., Jaafar, S.N.S. \& Roslan, R. 2015. Mechanical properties and water absorption of glass fibre reinforced bio-phenolic elastomer (BPE) composite. Industrial Crops and Products 72: 54-59.

Auad, M.L., Zhao, L., Shen, H., Nutt, S.R. \& Sorathia, U. 2007. Flammability properties and mechanical performance of epoxy modified phenolic foams. Journal of Applied Polymer Science 104: 1399-1407.

Azahari, N.A.,Zakaria, S., Kaco, H., Yee, G.S., Chia, C.H., Jaafar, S.N.S. \& Sajab, M.S. 2017. Regenerated kenaf cellulose membrane from $\mathrm{NaOH} /$ urea aqueous solution by coagulating with sulphuric acid. Sains Malaysiana 46(5): 795-801.

Chen, Z., Zeng, W., Chen, Y., Li, W. \& Liu, H. 2012. Influence of $\mathrm{F} / \mathrm{P}$ on structure and thermal property of phenolic resin. Key Eng. Mater. 500: 98-103.

Effendi, A., Gerhauser, H. \& Bridgwater, A.V. 2008. Production of renewable phenolic resins by thermochemical conversion of biomass: A review. Renewable and Sustainable Energy Reviews 12(8): 2092-2116.
Gan, S., Zakaria, S., Chen, R.S., Chia, C.H., Padzil, F.N.M. \& Moosavi, S. 2017. Autohydrolysis processing as an alternative to enhance cellulose solubility and preparation of its regenerated bio-based materials. Materials Chemistry and Physics 192: 181-189.

Gani, A. \& Naruse, I. 2007. Effect of cellulose and lignin content on pyrolysis and combustion characteristics for several types of biomass. Renewable Energy 32(4): 649-661.

Hamzah, R., Bakar, M.A., Khairuddean, M., Mohammed, I.A. \& Adnan, R. 2012. A structural study of epoxidized natural rubber (ENR-50) and its cyclic dithiocarbonate derivative using NMR spectroscopy techniques. Molecules 17(9): 10974-10993.

Haupt, R.A. \& Sellers, T. Jr. 1994. Characterizations of phenolformaldehyde resol resins. Industrial \& Engineering Chemistry Research 33(3): 693-697.

Hu, L., Zhou, Y. \& Liu, R. 2012. Characterization and properties of a lignosulfonate-based phenolic foam. Bioresources 7(1): 554-564.

Kallitsis, J.K. \& Kalfoglou, N.K. 1989. Compatibility of epoxidized natural rubber with thermoplastic and thermosetting resins. Journal of Applied Polymer Science 37(2): 453-465.

Kaynak, C. \& Cagatay, O. 2006. Rubber toughening of phenolic resin by using nitrile rubber and amino silane. Polymer Testing 25(3): 296-305.

Lee, S.H., Teramoto, Y. \& Shiraishi, N. 2002. Resol-type phenolic resin from liquefied phenolated wood and its application to phenolic foam. Journal of Applied Polymer Science 84(3): 468-472.

Lenghaus, K., Qiao, G.G. \& Solomon, D.H. 2001. The effect of formaldehyde to phenol ratio on the curing and carbonisation behaviour of resole resins. Polymer 42(8): 3355-3362.

Lin, L., Yoshioka, M., Yao, Y. \& Shiraishi, N. 1994. Liquefaction of wood in the presence of phenol using phosphoric acid as a catalyst and the flow properties of the liquefied wood. Journal of Applied Polymer Science 52(11): 1629-1636.

Ohsawa, T., Nakayama, A., Miwa, M. \& Hasegawa, A. 1978. Temperature dependence of critical fiber length for glass fiber-reinforced thermosetting resins. Journal of Applied Polymer Science 22(11): 3203-3212.

Phinyocheep, P., Phetphaisit, C.W., Derouet, D., Campistron, I. \& Brosse, J.C. 2005. Chemical degradation of epoxidized natural rubber using periodic acid: Preparation of epoxidized liquid natural rubber. Journal of Applied Polymer Science 95(1): 6-15.

Pizzi, A. 2003. Phenolic resin adhesives. In Handbook of Adhesive Technology. Second Edition, Revised and Expanded, edited by Pizzi, A. \& Mittal, K.L. Boca Raton: CRC Press. p. 541.

Pua, F.L., Zakaria, S., Chia, C.H., Fan, S.P., Rosenau, T., Potthast, A. \& Liebner, F. 2013. Solvolytic liquefaction of oil palm empty fruit bunch (EFB) fibres: Analysis of product fractions using FTIR and Pyrolysis-GCMS. Sains Malaysiana 42(6): 793-799.

Roslan, R., Zakaria, S., Chia, C.H., Boehm, R. \& Laborie, M.P 2014. Physico-mechanical properties of resol phenolic adhesives derived from liquefaction of oil palm empty fruit bunch fibres. Industrial Crops and Products 62: 119-124.

Siti Noorul Aina Ab Rahim, Sarani Zakaria., Sharifah Nabihah Syed Jaafar, Chin Hua Chia, Rasidi Roslan, Hatika Kaco \& Sinyee Gan. 2017. As-spun bio-novolac fiber morphological study based on resin's physico-chemical properties. Sains Malaysiana 46(9): 1659-1665. 
Sreekala, M.S., George, J., Kumaran, M.G. \& Thomas, S. 2002. The mechanical performance of hybrid phenol-formaldehydebased composites reinforced with glass and oil palm fibres. Composites Science and Technology 62(3): 339-353.

Zuhaili Zakaria, Sarani Zakaria*, Chin Hua Chia,

Sharifah Nabihah Syed Jaafar, Umar Adli Amran \& Sinyee Gan* Bioresources and Biorefinery Laboratory

Faculty Science and Technology

Universiti Kebangsaan Malaysia

43600 UKM Bangi, Selangor Darul Ehsan

Malaysia
Rasidi Roslan

Faculty of Industrial Sciences \& Technology

Universiti Malaysia Pahang, Lebuhraya Tun Razak 26300 Gambang Kuantan, Pahang Darul Makmur Malaysia

*Corresponding author; email: szakaria@ukm.edu.my

Received: 1 March 2018

Accepted: 13 June 2018 